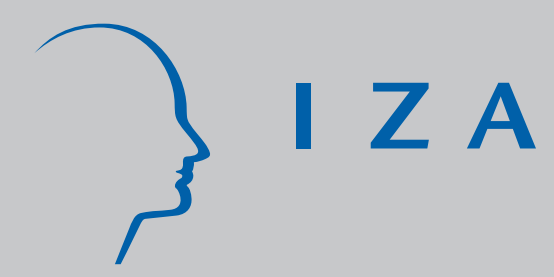

IZA DP No. 435

Perceived Income, Promotion and Incentive Effects

Gil S. Epstein

Melanie E. Ward

February 2002 


\title{
Perceived Income, Promotion and Incentive Effects
}

\author{
Gil S. Epstein \\ Bar-llan University, CEPR and IZA, Bonn \\ Melanie E. Ward \\ IZA, Bonn and CEPR
}

\author{
Discussion Paper No. 435 \\ February 2002
}

IZA

P.O. Box 7240

D-53072 Bonn

Germany

Tel.: +49-228-3894-0

Fax: +49-228-3894-210

Email: iza@iza.org

This Discussion Paper is issued within the framework of IZA's research area Mobility and Flexibility of Labor. Any opinions expressed here are those of the author(s) and not those of the institute. Research disseminated by IZA may include views on policy, but the institute itself takes no institutional policy positions.

The Institute for the Study of Labor (IZA) in Bonn is a local and virtual international research center and a place of communication between science, politics and business. IZA is an independent, nonprofit limited liability company (Gesellschaft mit beschränkter Haftung) supported by the Deutsche Post AG. The center is associated with the University of Bonn and offers a stimulating research environment through its research networks, research support, and visitors and doctoral programs. IZA engages in (i) original and internationally competitive research in all fields of labor economics, (ii) development of policy concepts, and (iii) dissemination of research results and concepts to the interested public. The current research program deals with (1) mobility and flexibility of labor, (2) internationalization of labor markets, (3) the welfare state and labor markets, (4) labor markets in transition countries, (5) the future of labor, (6) evaluation of labor market policies and projects and (7) general labor economics.

IZA Discussion Papers often represent preliminary work and are circulated to encourage discussion. Citation of such a paper should account for its provisional character. A revised version may be available on the IZA website (www.iza.org) or directly from the author. 
IZA Discussion Paper No. 435

February 2002

\section{ABSTRACT}

\section{Perceived Income, Promotion and Incentive Effects*}

This paper examines the disincentive effects of perceived underpayment on individuals' exerted effort and promotion. To this end we develop a theoretical framework and obtain empirical evidence by analysing British academia data. We find that, tenured academics will tend to invest less effort in publishing as the difference between their perceived deserved income and actual income increases. On the other hand, for non-tenured academics this relationship is ambiguous. Our model predicts that if, however, tenured staff also derive utility directly from publication, over and above that associated with income and promotion, the difference between perceived and actual income has a smaller negative effect on the actual effort invested in research.

JEL Classification: J3, J4

Keywords: Perceived income, underpayment, productivity, promotion

Gil S. Epstein

Department of Economics

Bar-Ilan University

52900 Ramat-Gan

Israel

Tel.: +972 - 3 - 5318937

Fax: +972 - 3 - 5353180

E-mail: epsteig@mail.biu.ac.il

\footnotetext{
*The authors gratefully acknowledge funding provided by the Scottish Economic Society.
} 


\section{Introduction}

This paper investigates the disincentive effects of underpayment on individual productivity. We are interested in the relationship between the effort invested by a worker at the work place and the difference between perceived deserved income and actual income received. Many firms have difficulty in assessing their employees' contribution to total output and profits (Radner 1993), as a consequence, workers may earn less or more than they think they deserve. Does the payment of workers above or below their perceived marginal revenue product have defined effects on their effort on the job?

The economics literature to date includes a discussion on workers' attempts to influence their employers' promotion review decisions - Milgrom and Robert (1992) define such activities as "influence costs", where through rent-seeking activity individuals earn rents in the form of promotion. Epstein and Spiegel (2001) take an alternative approach. They consider the effect of the difference between perceived income and actual income on influence costs and thus explain why the effect of income inequality on productivity and growth is ambiguous. In this paper we investigate the effect the difference between perceived income and actual income has on the level of effort invested by the worker in productive activities.

We first develop a theoretical framework to analyse this relationship. We consider a two period model. In the first period a worker determines how much effort to invest at the workplace. In the second period the worker is either promoted (with an associated salary rise) or not. The probability of promotion is a direct function of the effort invested in the first period. The worker, while making his/her decisions regarding the level of effort to invest in the first period takes into account the difference between his/her actual income earned and that which he/she thinks is deserved. As we show, as the difference between the two incomes (the perceived/deserved and the actual) increases, the level of effort invested by the worker may either increase or decrease. In general if the worker believes he/she should be earning more, then the worker is either discouraged and invests less effort or contrarily, is encouraged to increase effort to "prove" to superiors that he/she is worthy of the promotion. We develop conditions under which the workers will increase or decreases their level of effort as a result of an increase in the difference between perceived and actual income.

In order to examine this relationship empirically we use individual data from a sample of British academics from 5 old established universities. The British academic profession provides an interesting application for our analysis. The Hay report, published in 1997, suggested that over the ten-year period 1987-1996 university pay in Britain dropped a staggering 20\% in real terms, falling behind the remuneration levels of comparable professions in the public sector. Dearing (1997) 
confirmed this trend, warning that although academic remuneration should be sufficient to recruit, retain and motivate staff of the required quality, the majority of staff in British higher education were in fact paid substantially below comparable private and public sector rates. Concern was that the long-term underpayment of academics might decrease productivity, and/or may spark the drain of high quality individuals from academia into more lucrative positions in the private sector, or to academic positions abroad.

An advantage of the study of this particular labour market is that productivity is relatively easy to observe and quantify. The emergence of the research assessment exercise ${ }^{3}$ in Britain has emphasised the importance of publication to an academic career. Our dataset includes detailed information on individual research productivity, measured through the number of publications held by an individual. Our data also contains information on annual salary and on a measure of an academic's perceived or deserved salary. It has been suggested that academics as an occupational group may be less concerned about salary than the average worker, with non-pecuniary aspects of the job such as rewarding work taking precedence over salary. We consider the case that individuals derive utility from their job, over and above that derived from salary, during the course of our analysis. One might however wish to see the estimates derived from our empirical analysis as a lower bound estimate of the relationship between effort and reward.

The remainder of the paper is organised as follows. Section 2 introduces a theoretical model that investigates the relationship between the level of effort and the difference between the perceived and actual income of the worker. Section 3 introduces our dataset, summary statistics derived from our sample and discusses the empirical results. Section 4 concludes.

\section{The Model}

Our analysis focuses on the relationship between the effort invested by a worker at the work place and the difference between that worker's deserved income (that is the income that he or she thinks he/she deserves) and the actual income he/she receives. Since our empirical analysis is based on academic data, so we introduce our model in terms of publications and time invested in research activities and annual salary. Our theoretical and empirical results have however a more general application.

Each academic determines optimally how much time to spend in research activities, which may in turn yield publications in refereed journals. In order to simplify our story we assume that each academic has one unit of time, which he/she divides optimally between two alternatives: 
leisure and effort spent in research. Denote $L$ the level of leisure and $e$ the amount of effort invested in research activities, thus

$$
L+e=1
$$

Academics differ in their research abilities. In order to simplify our analysis we focus on a "representative" academic, who can be thought of as an "average" academic. We consider the number of publications the representative academic generates which is assumed to be a positive function of his/her time expenditure in research activities. Denote $P u b(e)$ as the number of publications a representative academic produces, given $e$ units of effort.

We consider a two period model. In the first period the academic earns an income of $I_{l}$ and must determine how much effort to invest in research activities. This effort will generate publications and as a result, with probability $P$ the academic will be promoted and receive a higher income of $I_{2}$ in the second period $\left(I_{2}>I_{1}\right)$. With probability $1-P$ the academic is not promoted and will earn the same income he received in the first period. The probability of promotion is a direct function of the number of average publications, thus the probability of promotion is also a positive function of the effort invested in research activities: $P(e)$ such that $\frac{\partial P}{\partial e} \geq 0$. It may be the case that an academic cannot be promoted in the future, since he/she may already hold a professorial position. Moreover, we could also think about promotion as the tenure hurdle - the probability of those that have tenure of receiving tenure is zero.

We simplify our analysis by assuming that the level of income is independent of the effort level. For the particular profession that we consider in our empirical section - that is British academia - this is a realistic assumption, since salaries within grades are based on a fixed salary structure and rise automatically in annual increments, irrespective of an individual's effort on the job. Allowing for the income, $I$, to be a function of the number of publications and thus also a function of the level of effort would however not change our main results ${ }^{4}$.

Let us now consider the utility of the representative academic, $u$. An individual's utility is a function of a number of parameters: first, it is positively related to an academic's leisure time, $L$; second, it is positively related to an academic's actual income, $I_{l}$; it is positively related to the number of publications published (this assumes that an academic derives utility from his/her job

\footnotetext{
${ }^{3}$ The research assessment exercise grades departments within UK universities on the basis of individual members' research output. Assessment in undertaken every 5 years.

${ }^{4}$ Proofs of propositions under the case that income is a function of effort in research activities is available on request.
} 
over and above that associated with income ${ }^{5}$ ); and, finally, it is negatively related to the difference between the income a worker thinks he/she should earn, $I^{e}$, that is deserved income, and the actual income he/she receives, $I$. The difference between the income that he or she thinks he/she deserves, and the actual income that he/she actually receives is denoted by $A=I^{e}-I{ }^{6}$

The representative academic's utility in the first period can therefore be written as follows:

$$
u_{1}=u_{1}\left(L_{1}, I_{1}, P u b_{1}, A_{1}\right)
$$

The academic's expected utility in the second period is given by:

$$
E\left[U_{2}\right]=P(e) u_{2}\left(L_{2}, I_{2}, P u b_{2}, A_{2}\right)+(1-P(e)) u_{3}\left(L_{2}, I_{1}, P u b_{2}, A_{3}\right)
$$

such that $\frac{\partial u_{i}(.)}{\partial L_{i}}>0, \frac{\partial u_{i}(.)}{\partial I_{i}}>0, \frac{\partial u_{i}(.)}{\partial P u b_{i}}>0$ and $\frac{\partial u_{i}\left(L_{i}, I_{i}, P u b_{i},\right)}{\partial A_{i}}<0$.

We assume that the level of effort invested in the first period determines the number of publications published in the second. In the first period an academic therefore takes as given his income level, $I_{l}$, the publications he/she held on entry to his/her current position (if any), $P u b_{l}$, and the difference between his perceived income and his actual income, $A_{1}$. An academic then decides on his investment in research which may yield a promotion at the end of period 1 , resulting in a higher income in the second period and a new difference between actual and deserved income, $A_{2}$. If the academic is not promoted, however, he will continue to earn $I_{1}$ while his deserved income will have risen, thus $A_{3}>A_{1}$. It is clear therefore that $A_{2}$ and $A_{3}$ are a function of the effort invested in the first period.

The expected utility of the representative academic over both periods is given by

\footnotetext{
5 This might be seen, for example, as the satisfaction derived from successful publication, international recognition, internal departmental politics, enjoying research itself, the opportunity to attend conferences, etc.

${ }^{6}$ Epstein and Spiegel (2001) look at the difference between what the worker contributes to the firm and what he/she earns.
} 


$$
\begin{aligned}
& E[U]= \\
& \begin{aligned}
=u_{1}\left(L_{1}, I_{1}, P u b_{1}, A_{1}\right)+ & P(e) u_{2}\left(L_{2}, I_{2}, P u b_{2}(e), A_{2}(e)\right)+ \\
& +(1-P(e)) u_{3}\left(L_{2}, I_{1}, P u b_{2}(e), A_{3}(e)\right)
\end{aligned}
\end{aligned}
$$

s.t.

$$
L+e=1
$$

The academic's objective is therefore to determine the optimal amount of effort to invest in the first period. The first order conditions are given $b^{7}$

$$
\begin{aligned}
& \frac{\partial E[U]}{\partial e}= \\
& =-\frac{\partial u_{1}}{\partial L_{1}}+\frac{\partial P(e)}{\partial e}\left(u_{2}(.)-u_{3}(.)\right)+ \\
& +P(e)\left(\left(\frac{\partial u_{2}}{\partial P u b_{2}}-\frac{\partial u_{3}}{\partial P u b_{2}}\right) \frac{\partial P u b_{2}}{\partial e}+\frac{\partial u_{2}}{\partial A_{2}} \frac{\partial A_{2}}{\partial e}-\frac{\partial u_{3}}{\partial A_{3}} \frac{\partial A_{3}}{\partial e}\right) \\
& \\
& +\frac{\partial u_{3}}{\partial P u b_{2}} \frac{\partial P u b_{2}}{\partial e}+\frac{\partial u_{3}}{\partial A_{3}} \frac{\partial A_{3}}{\partial e}=0
\end{aligned}
$$

Thus,

$$
\begin{aligned}
\frac{\partial u_{1}}{\partial L_{1}}= & \frac{\partial P(e)}{\partial e}\left(u_{2}(.)-u_{3}(.)\right)+ \\
& +P(e)\left(\left(\frac{\partial u_{2}}{\partial P u b_{2}}-\frac{\partial u_{3}}{\partial P u b_{2}}\right) \frac{\partial P u b_{2}}{\partial e}+\frac{\partial u_{2}}{\partial A_{2}} \frac{\partial A_{2}}{\partial e}-\frac{\partial u_{3}}{\partial A_{3}} \frac{\partial A_{3}}{\partial e}\right) \\
& +\frac{\partial u_{3}}{\partial P u b_{2}} \frac{\partial P u b_{2}}{\partial e}+\frac{\partial u_{3}}{\partial A_{3}} \frac{\partial A_{3}}{\partial e}
\end{aligned}
$$

\footnotetext{
${ }^{7}$ Assuming that second order condition holds.
} 
The LHS represents the marginal cost of the investment - the decrease in leisure resulting from an increase in effort invested in research. On the RHS we see the marginal benefit of investing effort in research, $\frac{\partial P(e)}{\partial e}\left(u_{2}()-.u_{3}().\right)$ represents the marginal probability times the increase in utility as a result of winning the promotion. $\quad P(e)\left(\left(\frac{\partial u_{2}}{\partial P u b_{2}}-\frac{\partial u_{3}}{\partial P u b_{2}}\right) \frac{\partial P u b_{2}}{\partial e}+\frac{\partial u_{2}}{\partial A_{2}} \frac{\partial A_{2}}{\partial e}-\frac{\partial u_{3}}{\partial A_{3}} \frac{\partial A_{3}}{\partial e}\right)$ represents the marginal increase in utility multiplied by the probability of winning the promotion. $\left(\frac{\partial u_{2}}{\partial P u b_{2}}-\frac{\partial u_{3}}{\partial P u b_{2}}\right) \frac{\partial P u b_{2}}{\partial e}$ represents the marginal effect of an increase in effort on utility through additional publication. Notice that assuming a decreasing marginal utility of the number of publications we obtain that $\frac{\partial u_{2}}{\partial P u b_{2}}-\frac{\partial u_{3}}{\partial P u b_{2}}<0 \cdot \frac{\partial u_{2}}{\partial A_{2}} \frac{\partial A_{2}}{\partial e}-\frac{\partial u_{3}}{\partial A_{3}} \frac{\partial A_{3}}{\partial e}$ represents the marginal effect of an increase in the level of effort on utility via the difference between deserved income and actual income. It is natural to assume that $\frac{\partial A_{2}}{\partial e}<0$ and $\frac{\partial A_{3}}{\partial e}>0$ namely, increasing effort will decrease $A$ if an academic wins a promotion, while it will increase $A$ if an academic looses the promotion $^{8}$, therefore $\frac{\partial u_{2}}{\partial A_{2}} \frac{\partial A_{2}}{\partial e}-\frac{\partial u_{3}}{\partial A_{3}} \frac{\partial A_{3}}{\partial e}>0$. The last term $\frac{\partial u_{3}}{\partial P u b_{2}} \frac{\partial P u b_{2}}{\partial e}+\frac{\partial u_{3}}{\partial A_{3}} \frac{\partial A_{3}}{\partial e}$ represents the marginal effect of increasing effort on utility when not receiving promotion. The first term is the positive effect of an increase in publications while the second effect represents the negative effect of increasing effort and increasing the difference between deserved and actual income. The sum may be either negative or positive.

We denote the level of effort that satisfies (6) by $e^{*}$. We are now interested in investigating what effect a change in $A_{1}$ has on individual productivity, measured by the effort/number of publications invested/produced by the representative academic. Thus we calculate: $\frac{\partial e^{*}}{\partial A_{1}}$. It can be verified that $\frac{\partial e^{*}}{\partial A_{1}}=-\frac{\frac{\partial^{2} E[U]}{\partial e \partial A_{1}}}{\frac{\partial^{2} E[U]}{\partial e^{2}}}$, thus the sign of $\frac{\partial e^{*}}{\partial A_{1}}$ is the same as that of $\frac{\partial^{2} E[U]}{\partial e \partial A_{1}}$. Thus we calculate $\frac{\partial^{2} E[U]}{\partial e \partial A_{1}}$

\footnotetext{
${ }^{8}$ One could argue that $A_{2}$ may increase even if the academic wins the promotion as both the perceived income and the actual income will increase. We simplify our calculations by assuming that this doesn't happen. In general our results
} 


$$
\begin{aligned}
& \frac{\partial^{2} E[U]}{\partial e \partial A_{1}}=-\frac{\partial^{2} u_{1}}{\partial L_{1} \partial A_{1}}+\frac{\partial P(e)}{\partial e} \frac{\partial\left(u_{2}(.)-u_{3}(.)\right)}{\partial A_{1}}+ \\
& \quad+P(e)\left(\left(\frac{\partial^{2} u_{2}}{\partial P u b_{2} \partial A_{1}}-\frac{\partial^{2} u_{3}}{\partial P u b_{2} \partial A_{1}}\right) \frac{\partial P u b_{2}}{\partial e}+\frac{\partial^{2} u_{2}}{\partial A_{2} \partial A_{1}} \frac{\partial A_{2}}{\partial e}-\frac{\partial^{2} u_{3}}{\partial A_{3} \partial A_{1}} \frac{\partial A_{3}}{\partial e}\right) \\
& \quad+\frac{\partial^{2} u_{3}}{\partial P u b_{2} \partial A_{1}} \frac{\partial P u b_{2}}{\partial e}+\frac{\partial^{2} u_{3}}{\partial A_{3} \partial A_{1}} \frac{\partial A_{3}}{\partial e}
\end{aligned}
$$

It is assumed that $u_{i}$ exhibits decreasing returns to our various variables thus, $\frac{\partial^{2} u_{1}}{\partial L_{1}{ }^{2}}<0, \frac{\partial^{2} u_{i}(.)}{\partial A_{1}{ }^{2}}<0, \frac{\partial^{2} u_{i}}{\partial P u b_{2}{ }^{2}}<0$ and $\frac{\partial^{2} u_{i}}{\partial A_{i}{ }^{2}}<0$. Together with the natural assumptions regarding our first order derivatives we obtain:

$$
\frac{\partial^{2} u_{1}}{\partial L_{1} \partial A_{1}}>0, \frac{\partial^{2} u_{2}}{\partial P u b_{2} \partial A_{1}}>0, \frac{\partial^{2} u_{3}}{\partial P u b_{2} \partial A_{1}}>0, \frac{\partial^{2} u_{2}}{\partial A_{2} \partial A_{1}}<0 \text { and } \frac{\partial^{2} u_{3}}{\partial A_{3} \partial A_{1}}<0 \text {. }
$$

Let us first consider the extreme case where the probability of promotion is very small or doesn't exist at all. This case will hold for all those academics that have tenure or do not believe that they will be promoted. Under this case $P(e)=\frac{\partial P(e)}{\partial e}=0$ therefore,

$$
\left.\frac{\partial^{2} E[U]}{\partial e \partial A_{1}}\right|_{\frac{\partial P(e)}{\partial e}=P(e)=0}=-\frac{\partial^{2} u_{1}}{\partial L_{1} \partial A_{1}}+\frac{\partial^{2} u_{3}}{\partial P u b_{2} \partial A_{1}} \frac{\partial P u b_{2}}{\partial e}+\frac{\partial^{2} u_{3}}{\partial A_{3} \partial A_{1}} \frac{\partial A_{3}}{\partial e}
$$

The effect on leisure is negative while the effect on publication is positive and the effect of the difference between deserved and actual income is also negative. We therefore obtain,

Result 1: If the academic has a low or no probability of being promoted then:

If the academic is only (or mostly) concerned with publications (a "true" academic) he will increase his effort (if possible) in research activities.

If the academic is also concerned about his leisure and his/her deserved verses actual income, then the effect of an increase in A on the level of effort is ambiguous. 
This result states that if an academic cannot be promoted, but is only concerned about publication then he will invest all his time in publication. If, however, he is also concerned about the difference between his deserved and actual income and about his leisure time, then he may increase or decrease the time invested in research activities.

Now let us turn to the case where an academic may be promoted. Notice that in comparison to the case where an academic will not be promoted (8) we now have to take into consideration one more element (7): the effect on the future utility if promoted:

$$
\begin{aligned}
& \frac{\partial P(e)}{\partial e} \frac{\partial\left(u_{2}(.)-u_{3}(.)\right)}{\partial A_{1}}+ \\
& P(e)\left(\left(\frac{\partial^{2} u_{2}}{\partial P u b_{2} \partial A_{1}}-\frac{\partial^{2} u_{3}}{\partial P u b_{2} \partial A_{1}}\right) \frac{\partial P u b_{2}}{\partial e}+\frac{\partial^{2} u_{2}}{\partial A_{2} \partial A_{1}} \frac{\partial A_{2}}{\partial e}-\frac{\partial^{2} u_{3}}{\partial A_{3} \partial A_{1}} \frac{\partial A_{3}}{\partial e}\right)
\end{aligned}
$$

Note that $\frac{\partial P(e)}{\partial e}>0, \frac{\partial P u b_{2}}{\partial e}>0$ and given what we have described above, it is clear that $\frac{\partial^{2} u_{2}}{\partial P u b_{2} \partial A_{1}}-\frac{\partial^{2} u_{3}}{\partial P u b_{2} \partial A_{1}}>0$ and $\frac{\partial^{2} u_{2}}{\partial A_{2} \partial A_{1}} \frac{\partial A_{2}}{\partial e}-\frac{\partial^{2} u_{3}}{\partial A_{3} \partial A_{1}} \frac{\partial A_{3}}{\partial e}>0$. The sign of the term $\frac{\partial\left(u_{2}(.)-u_{3}(.)\right)}{\partial A_{1}}$ is positive, since the effect of $A$ when one has been promoted should be smaller than that when the person hasn't been promoted (remember that $u_{2}()-.u_{3}()>$.0 and that the utility has a decreasing margin with regard to $A$ ). We have therefore added three new components to (8) which all are positive. We may conclude therefore that

Result 2: If the academic believes he/she may be promoted as a result of increasing his/her effort he/she will invest more time and effort in research activities than the academic, with the same attributes, that doesn't believe he/she will be promoted.

To conclude, from results 1 and 2 and the above analysis we hypothesise that an academic believing that he/she earns less than he/she deserves, may in turn (1) increase effort on the job in order to prove their worth for a promotion or, (2) decrease research activities in the face of insufficient pecuniary reward. An academics response may hinge critically on the probability of promotion. In other words, tenured academics will tend to publish less as the difference between the income they 
think they deserved and actual income increases. On the other hand, non-tenured academics may increase or decrease the effort invested in research activities as the difference between deserved and actual income increases.

In section 4 we turn to look at the empirical evidence on incentives effects on productivity in British academia. Section 3 first introduces the data source and it's main characteristics.

\section{Data}

The data used in this paper come from a cross section study undertaken in 1995/1996 of the academic staff of five old established British universities: Aberdeen, Dundee, Glasgow, Heriot-Watt and St. Andrews. The data was collected by means of a postal questionnaire, sent to the entire academic population, across all disciplines, of each university. 'Academic staff' included professors, readers, senior lecturers and lecturers, research assistants and fellows. The personnel department of each university compiled a current list of staff, and questionnaires, including instructions for completion, were distributed through the internal mail service of each university, anonymously completed by respondents and returned. The questionnaire collected information on personal background, education, working history and current job. The average response rate achieved was $30 \%$, resulting in detailed information on 878 academics $^{9}$. The data is weighted by gender, rank and subject area, and in these aspects is representative.

An advantage of this dataset for our analysis is it's detail. It provides detailed information on individual productivity, measured by the number of publications held by an individual, actual annual salary and an indication of whether actual salary reflects that which individuals consider they deserve. Ideally one might also wish to have information on research quantity, but unfortunately the quality of research is very hard to measure across all disciplines. Unless one wanted to concentrate on a narrowly defined subject field, where quality is clearly defined, quantity should represent a reasonable measure of research output. Annual salary is reported gross, before deductions for tax, national insurance, etc. A measure of the difference between the income that an academic feels he/she deserves, and the actual income that he/she receives is provided by individual response to the question: 'All things considered, which of the following statements do you feel best describes your present salary?: (i) Much less than I deserve, (ii) Somewhat less than I deserve, (iii) About what I deserve, (iv) Somewhat more than I deserve and (v) Much more than I deserve'.

The comparative disadvantage of the dataset is its' cross sectional nature. We are only able to analyse a snap-shot of the academic profession at one point in time without the ability to correct

\footnotetext{
${ }^{9}$ The limited availability of statistics for the UK academic population makes it difficult to comment to what extent our data is representative. Comparison with summary information on the parent population of academics in Scotland made available by the university personnel departments reveals that females are marginally over-represented in our dataset. Across rank and subject area, at least, the data are representative of the academic population.
} 
for selection in and out of the profession, nor are we able to observe the dynamic effects of underpayment on individual effort. This restriction is an important caveat to our analysis. Nevertheless the analysis of the cross sectional picture introduces some interesting propositions, to be challenged by future research.

\section{[TABLES 1 AND 2 ABOUT HERE ]}

Table 1 presents the definitions of the explanatory variables used in our empirical analysis. Of the 878 academics from whom information was collected, we select fulltime academics, those paid on the non-clinical scale and those academics that are under the age of 64. Dropping those cases with missing information, we are left with 689 observations. Table 2 reports summary statistics for our variables of interest. From the first column we see that in our sample of academics $70 \%$ are male, and $89 \%$ are UK citizens. Our academics hold on average around 17 years of experience, nearly 10 years of which have been spent with their current university. Forty percent of academics are employed on a contract with less than a 3 year's duration (or in other words, $60 \%$ are tenured). Academics work over 50 hours per week on average, taking 24 days holiday per year. The table shows that the number of published papers is considerably higher on average in Science. The clear differences in research output by subject field highlights the necessity to control for subject field in our analysis. One way to do this would be to estimate the research ouput by scientific field, but our relatively small number of observations does not favour such an approach. Instead we normalize the number of papers by subtracting means and dividing by standard errors by subject field. This also allows us to consider what it takes to publish more than the average in an academic's field. The last panel of table 2 presents statistics on academics' actual and perceived salaries. We see that the majority of academics report that they receive a lower salary than they feel they deserve (79\%), a large proportion report that they receive much less than they deserve (18\%). Colomns 2 to 6 break all statistics down by contract type (short term or tenured) and grade.

\section{[TABLES 3 and 4 ABOUT HERE ]}

Table 3 presents simple OLS regression on the determinants of individual productivity of the form:

$$
P_{i}=\alpha_{i}+\beta_{1 i} P C_{i}+\beta_{2 i} J C_{i}+\beta_{3 i} U_{i}+\varepsilon_{i}
$$


Where $P_{i}$ is the number of refereed publications normalised by subject field, $P C_{i}$ is a vector of personal characteristics of the individual, $J C_{i}$ is a vector of job characteristics and $U_{i}$ represents the gap between actual and deserved salary of an individual. The first column in table 3 presents the results of this regression, excluding underpayment variables, for the whole of our sample. Interesting results to mention are that (1) we reveal a significant male advantage in publication output, (2) experience, tenure and holding a $\mathrm{PhD}$ are important predictors of publication success, and (3) hours of work are not significant in the determination of academic productivity.

The career path of the average academic entails two important hurdles - achieving tenure that is acquiring a permanent position at an institution, and getting promoted from grade to grade. The first interpretation of the extreme case of our model - that is that the probability of promotion is very small or doesn't exist at all - is the case when an individual is already tenured. Columns 2 and 3 of table 3 therefore split our sample into those academics with a tenured position and those on short-term contracts. From column 2 we now see that hours of work are a significant predictor of the productivity of tenured staff. In using the specification in equation (10) with cross sectional data one might be concerned about the direction of causality - underpayment may not be causing decrease in productivity, but rather low productivity may impact negatively on wage and hence on the difference between deserved and actual income. Without longitudinal data, we are unable to isolate the two effects. This split however allows us to consider a mixed bag of academics - the untenured, which will contain both talented academics and 'rejects', against a bag of talented tenured academics, hence, analysis of the latter group already conditions on a certain level productivity standard.

We are centrally concerned however with the possible disincentive effects of underpayment on individual productivity, more specifically the correlation between the productivity and the difference between the perceived and actual income. Columns 4 and 5 therefore include a dummy variable indicating those individuals that consider they deserve a higher salary than the currently receive (more), and those individuals that consider they deserve less (less). The base category here is those individuals that respond that they are paid about what they deserve. We see that the coefficient on perceived underpayment is significantly negative, for both tenured and short-term contract staff, this effect is only significant for tenured staff however ${ }^{10}$. Columns 6 and 7 now replace our more and less variables with more detailed information on the extent of any under or over payment that respondents perceive. We see that for tenured staff, the negative relationship between perceived underpayment and productivity increases in magnitude with the gap between

\footnotetext{
${ }^{10}$ Note that with cross sectional data we cannot say anything concrete about the direction of causality of this relationship.
} 
deserved and actual pay. Once again, this effect is only significant for tenured staff. Interestingly, when we run separate regressions for men and women (not reported here) this underpayment effect is found to only be significant for men.

Alternatively, a second interpretation of the extreme case of our model - that is that the probability of promotion is very small or doesn't exist at all - is the case when an individual already holds the position of professor. Combing grade information with information on tenure, we divide our sample into three groups, or grades, of academic. Grade 1 consists of researchers or lecturer A staff, who can be promoted to higher grades and are unlikely to hold tenured positions. Grade 2 consists of lecturer B staff, senior lecturers and readers, who are likely to hold tenured positions but can still be promoted, since they hold positions lower than the title of professor. Finally, Grade 3 consists of tenured professors $^{11}$ - those individuals who cannot be promoted along either of our two definitions.

\section{[TABLES 5 ABOUT HERE ]}

Table 4 presents our analysis of the determinates of productivity for these three grades of staff. The first three columns of table 4 exclude variables relating to deserved salary. Interesting results include (1) the persistence of a significant gender effect in productivity for grade 1 and 2, but not grade 3 staff and (2) the significant effect of a PhD from Oxford or Cambridge for grade 3 staff. Introduction of our more and less variables in columns 4 to 6 indicate the significantly positive relationship between being paid more than deserved for grade 1 staff and the significantly negative effect of underpayment for professors. Inclusion of our more detailed information on the extent of under and overpayment in columns 7 to 9 indicates that the magnitude of the negative relationship for professors increases with increasing distance between perceived and actual pay levels.

\section{Conclusion}

This paper investigates the disincentive effects of underpayment on individual productivity. We are interested in the relationship between the effort invested by a worker at the work place and the difference between the income that he or she thinks he/she deserves, and the income that he/she actually receives. In the first half of the paper we develop a theoretical model which suggests that an academic believing that he earns less than he deserves, may in turn (1) increase effort on the job in order to prove their worth for a promotion or, (2) decrease research activities in the face of insufficient pecuniary reward. We outline that an academics' response may hinge critically on the

\footnotetext{
${ }^{11}$ In fact this is equal to the number of professors, since all are tenured).
} 
probability of promotion and /or increase in income. In other words, holding human capital characteristics constant, tenured academics will tend to publish less as the difference between the income they think they deserved and actual income increases. On the other hand, non-tenured academics may increase or decrease the effort invested in research activities as the difference between deserved and actual income increases. Our model predicts that if, however, tenured staff also derive utility directly from publication other than that associated with income and promotion, the difference between perceived and actual income will have a smaller effect on the actual effort invested in research.

In the second half of the paper we look at empirical evidence to support our theoretical analysis and find that taking promotion as a tenure hurdle, we reveal no evidence of any significant relationship of pay on performance for contract staff, where performance is measured in relation to the average in one's field. For tenured staff however, our analysis reveals a significantly negative relationship between underpayment and productivity. This effect increases with the magnitude of the distance between perceived and actual salary. The direction of the relationship between underpayment and productivity is confirmed when taking promotion as a combination of tenure and promotion hurdle. We find that professors are likely to be increasingly less productive, as they consider themselves progressively underpaid. We also find evidence that junior staff, however, experience accelerated productivity as they regard themselves generously rewarded.

Hence it appears that underpayment has limited effects on productivity for those individuals who still have promotion or tenure opportunities. Underpayment may be particularly damaging to individuals who hold tenure/the title of professor are unsuccessful in salary negotiation and are limited in their outside options. One might question therefore why such individuals remain in academia at all. The answer may lie in the fact that academics do what they are good at - publishing and gaining international recognition, rather than earning money! 


\section{Bibliography}

Epstein G.S. and Spiegel U. (2001), "Natural Inequality, Production and Economic Growth", Labour Economics, (8)4, pp. 463-473.

Dearing (1997) National Committee of Inquiry into Higher Education, Higher Education in the Learning Society, Report of the National Committee, Main Report, HMSO.

Milgrom, P.R. and Roberts, J. (1992), Economics, Organization and Management, Englewood Cliffs, NJ: Prentice Hall.

Radner, R. (1993), "Hierarchy: The Economics of Managing," Journal of Economic Literature, 30(3), pp. 1382-1415 
Table 1: List of Variables

\begin{tabular}{|c|c|}
\hline Name & Definition \\
\hline $\begin{array}{l}\text { Individual characteristics } \\
\text { Male } \\
\text { UK Citizen } \\
\text { No of Kids } \\
\text { Married }\end{array}$ & $\begin{array}{l}=1 \text { if male, }=0 \text { if female } \\
=1 \text { if } U K \text { citizen, }=0 \text { otherwise } \\
\text { Number of children } \\
=1 \text { if married, }=0 \text { otherwise }\end{array}$ \\
\hline \multicolumn{2}{|l|}{ Job characteristics } \\
\hline Experience & Length of total labour market experience, measured in years \\
\hline Experience $\mathrm{Sq}$ & Experience Squared \\
\hline Tenure & Length of time with current employer, measured in years \\
\hline Tenure $\mathrm{Sq}$ & Tenure Squared \\
\hline Small Department & $=1$ if the respondent works in a department of 10 or less academic staff, $=0$ otherwise. \\
\hline Medium-sized department & $\begin{array}{l}=1 \text { if the respondent works in a department of more than } 10 \text { but less than } 40 \text { academic staff, }=0 \\
\text { otherwise. }\end{array}$ \\
\hline Large Department & $=1$ if the respondent works in a department of 40 or more academic staff, $=0$ otherwise. \\
\hline Oxbridge $P h D$ & $=1$ if holds a PhD from Oxford or Cambridge, $=0$ otherwise \\
\hline Having PhD & $=1$ if holds a PhD, = 0 otherwise \\
\hline Hours & Usual hours worked per week \\
\hline Holiday & Number of days holiday taken per year on average \\
\hline Time-out & Length of time out of labour force, measured in years \\
\hline \multicolumn{2}{|l|}{ Job position } \\
\hline Short-term contract & $=1$ if contract for 3 or less years, $=0$ otherwise \\
\hline Grade 1 & $=1$ if untenured staff member in grades of researcher, lecturer, senior lecturer or reader \\
\hline Grade 2 & $=1$ if tenured staff member in grades of researcher, lecturer, senior lecturer or reader \\
\hline Grade 3 & $=1$ if professor, $=0$ otherwise \\
\hline Faculty & $\begin{array}{l}\text { Dummies for the five faculties in which respondents work: Arts, Science, Engineering, Social } \\
\text { Sciences, Medicine }\end{array}$ \\
\hline \multicolumn{2}{|l|}{ Publications } \\
\hline No of Publications & Total number of refereed publications published \\
\hline $\begin{array}{l}\text { (No of Publications-mean in } \\
\text { field) / (Standard deviation in } \\
\text { field) }\end{array}$ & z-score of the total number of refereed publications published by subject field \\
\hline Salary & \\
\hline Much less than I deserve & $\begin{array}{l}=1 \text { if in reply to the question 'All things considered, which of the following statements do you feel } \\
\text { best describes your present salary?' respondent replied: 'Much less than I deserve', = } 0 \\
\text { otherwise. }\end{array}$ \\
\hline Less than I deserve & = 1 if respondent replied 'Somewhat less than I deserve', = 0 otherwise. \\
\hline $\begin{array}{l}\text { About what I deserve } \\
\text { Somewhat more than I } \\
\text { deserve }\end{array}$ & $\begin{array}{l}=1 \text { if respondent replied 'About what I deserve', = } 0 \text { otherwise. } \\
=1 \text { if respondent replied 'Somewhat more than I deserve, }=0 \text { otherwise. }\end{array}$ \\
\hline Much more than I deserve' & = 1 if respondent replied 'Much more than I deserve', = 0 otherwise. \\
\hline Less & $=1$ if respondent replied 'Much less than I deserve' or 'somewhat less than I deserve' \\
\hline $\begin{array}{l}\text { More } \\
\text { Annual Salary }\end{array}$ & $\begin{array}{l}=1 \text { if respondent replied 'Much more than I deserve' or 'somewhat more than I deserve' } \\
\text { Gross annual salary of respondent }\end{array}$ \\
\hline
\end{tabular}


Table 2: Summary Statistics

\begin{tabular}{|c|c|c|c|c|c|c|}
\hline Name & All & $\begin{array}{l}\text { Short term } \\
\text { staff }\end{array}$ & Tenured staff & Grade 1 & Grade 2 & Grade 3 \\
\hline \multicolumn{7}{|l|}{ Individual characteristics } \\
\hline Male & .70 & .54 & .81 & .54 & .77 & .96 \\
\hline UK Citizen & .89 & .85 & .91 & .83 & .91 & .96 \\
\hline No of Kids & $1.15(1.26)$ & $.54(.98)$ & $1.55(1.26)$ & $.51(.927)$ & $1.50(1.24)$ & $2.03(1.23)$ \\
\hline Married & .37 & .54 & .26 & .55 & .26 & .17 \\
\hline \multicolumn{7}{|l|}{ Job characteristics } \\
\hline Experience & $16.95(10.83)$ & $9.73(8.50)$ & $21.63(9.53)$ & $9.21(7.53)$ & $21.25(9.09)$ & $27.28(7.56)$ \\
\hline Tenure & $9.90(11.03)$ & $4.43(8.35)$ & $13.52(11.10)$ & $4.54(9.029$ & $13.20(10.19)$ & $16.43(11.53)$ \\
\hline Small Department & .47 & .41 & .52 & .41 & .55 & .47 \\
\hline Medium-sized department & .22 & .24 & .20 & .23 & .19 & .22 \\
\hline Large Department & .31 & .35 & .28 & .36 & .26 & .31 \\
\hline Oxbridge $P h D$ & .09 & .04 & .14 & .04 & .12 & .2 \\
\hline Having $P h D$ & .70 & .61 & .77 & .64 & .73 & .81 \\
\hline Hours & $50.86(11.36)$ & $46.89(11.46)$ & $53.49(10.52)$ & $47.40(11.47)$ & $52.24(9.80)$ & $57.21(11.62)$ \\
\hline Holiday & $24.10(9.18)$ & $25.52(9.23)$ & $23.16(9.05)$ & $25.18(9.31)$ & $23.91(9.06)$ & $21.47(8.69)$ \\
\hline Time-out & $.54(1.90)$ & $.83(2.31)$ & $.34(1.55)$ & $.85(2.54)$ & $.38(1.30)$ & $.06(.33)$ \\
\hline \multicolumn{7}{|l|}{ Job position } \\
\hline Short-term contract & .40 & - & - & - & - & - \\
\hline Grade 1 & .44 & - & - & - & - & - \\
\hline Grade 2 & .41 & - & - & - & - & - \\
\hline Grade 3 & .15 & - & - & - & - & - \\
\hline \multicolumn{7}{|l|}{ Publications } \\
\hline No of Publications & $21.66(33.23)$ & $8.67(23.80)$ & $30.26(35.72)$ & $6.23(10.70)$ & $24.32(26.49)$ & $59.44(54.76)$ \\
\hline No of Publications (science) & $29.55(42.67)$ & $10.62(30.84)$ & 45.95 (44.77) & $8.22(12.55)$ & 37.46 (33.59) & $91.33(67.60)$ \\
\hline $\begin{array}{l}\text { No of Publications (medicine) } \\
\text { No of Publications (social }\end{array}$ & $22.81(31.55)$ & $8.51(12.17)$ & $38.89(38.32)$ & $5.38(6.98)$ & $27.64(25.90)$ & $64.11(48.84)$ \\
\hline $\begin{array}{l}\text { science) } \\
\text { No of Publications }\end{array}$ & $14.62(21.30)$ & $2.87(6.90)$ & $18.14(22.83)$ & $2.09(3.07)$ & $12.22(12.93)$ & $39.09(30.19)$ \\
\hline (engineering) & $16.59(26.09)$ & $8.13(26.58)$ & $22.55(24.26)$ & $4.48(5.17)$ & $20.19(22.26)$ & $43.71(45.24)$ \\
\hline No of Publications (arts) & $12.63(15.90)$ & $4.35(8.21)$ & $14.59(16.67)$ & $5.29(8.05)$ & $12.49(11.03)$ & $27.31(28.48)$ \\
\hline \multicolumn{7}{|l|}{ Salary } \\
\hline Annual Salary & $\begin{array}{l}25,226.99 \\
(9782.14)\end{array}$ & $\begin{array}{l}18,498.12 \\
(6986.87)\end{array}$ & $\begin{array}{l}29,681.08 \\
(8773.78)\end{array}$ & $\begin{array}{l}17,923.34 \\
(4910.26)\end{array}$ & $\begin{array}{l}27,925.66 \\
(7013.97)\end{array}$ & $\begin{array}{l}39,102.27 \\
(8097.553)\end{array}$ \\
\hline Much less than I deserve & $.18(.39)$ & $.14(.35)$ & $.27(.41)$ & $.18(.38)$ & $.18(.39)$ & $.19(.40)$ \\
\hline Less than I deserve & $.52(.50)$ & $.49(.50)$ & $.54(.50)$ & $.48(.50)$ & $.58(.50)$ & $.49(.50)$ \\
\hline About what I deserve & $.27(.44)$ & $.33(.47)$ & $.23(.42)$ & $.32(.47)$ & $.22(.41)$ & $.29(.45)$ \\
\hline Somewhat more than I deserve & $.02(.15)$ & $.03(.17)$ & $.08(.13)$ & $.02(.15)$ & $.02(.14)$ & $.02(.14)$ \\
\hline Much more than I deserve & $.04(.07)$ & $.01(.08)$ & $.002(.05)$ & $.003(.06)$ & $.003(.06)$ & $.009(.10)$ \\
\hline Less & $.70(.46)$ & $.63(.48)$ & $.75(.43)$ & $.66(.48)$ & $.76(.43)$ & $.68(.47)$ \\
\hline More & $.03(.16)$ & $.06(.18)$ & $.02(.14)$ & $.03(.16)$ & $.02(.15)$ & $.03(.17)$ \\
\hline No of observations & 689 & 271 & 418 & 299 & 286 & 104 \\
\hline
\end{tabular}

Standard deviations in parentheses. 
Table 3: OLS

The determinants of individual productivity by contract type, dependent variable $=$ z-score of number of refereed publications by subject field

\begin{tabular}{|c|c|c|c|c|c|c|c|}
\hline No. of published papers & All & $\begin{array}{c}\text { Tenured } \\
\text { Staff }\end{array}$ & $\begin{array}{c}\text { Short-term } \\
\text { contract } \\
\text { holders } \\
\end{array}$ & $\begin{array}{c}\text { Tenured } \\
\text { Staff }\end{array}$ & \begin{tabular}{|c|} 
Short-term \\
contract \\
holders \\
\end{tabular} & $\begin{array}{c}\text { Tenured } \\
\text { Staff }\end{array}$ & $\begin{array}{c}\text { Short-term } \\
\text { contract } \\
\text { holders }\end{array}$ \\
\hline \\
\hline A lot less than I deserve & & & & & & $\begin{array}{l}-.280^{*} \\
(.148)\end{array}$ & $\begin{array}{l}-.062 \\
(.088)\end{array}$ \\
\hline Less than I deserve & & & & & & -.178 & -.062 \\
\hline & & & & & & $(.120)$ & $(.059)$ \\
\hline More than I deserve & & & & & & $\begin{array}{l}-.109 \\
(.362)\end{array}$ & $\begin{array}{l}.155 \\
(.173)\end{array}$ \\
\hline A lot more than I deserve & & & & & & $\begin{array}{c}-.122 \\
(1.221)\end{array}$ & $\begin{array}{l}.261 \\
(.990)\end{array}$ \\
\hline Less & & & & $-.205^{*}$ & -.062 & & \\
\hline More & & & & $\begin{array}{l}(.111 \\
-.149)\end{array}$ & $\begin{array}{l}.057) \\
.158 \\
(.170)\end{array}$ & & \\
\hline \multicolumn{8}{|l|}{$\begin{array}{l}\text { Individual Characteristics } \\
\text { Male }\end{array}$} \\
\hline Male & $\begin{array}{l}.300^{* * *} \\
(.082)\end{array}$ & $\begin{array}{l}.457^{* * *} \\
(.145)\end{array}$ & $\begin{array}{l}.097^{*} \\
(.059)\end{array}$ & $\begin{array}{l}.463^{* * *} \\
(.145)\end{array}$ & $\begin{array}{l}.087 \\
(.060)\end{array}$ & $\begin{array}{l}.467^{* \star *} \\
(.145)\end{array}$ & $\begin{array}{l}.087 \\
(.060)\end{array}$ \\
\hline UK Citizen & $\begin{array}{l}0.107 \\
(.110)\end{array}$ & $\begin{array}{l}.259 \\
(.169)\end{array}$ & $\begin{array}{c}-.183^{* *} \\
(.091)\end{array}$ & $\begin{array}{l}.230 \\
(.170)\end{array}$ & $\begin{array}{l}-.165^{*} \\
(.091)\end{array}$ & $\begin{array}{l}.244 \\
(.171)\end{array}$ & $\begin{array}{l}-.165^{*} \\
(.092)\end{array}$ \\
\hline No. of Kids & $\begin{array}{l}.081^{* * *} \\
(.035)\end{array}$ & $\begin{array}{l}.028 \\
(.049)\end{array}$ & $\begin{array}{l}.218^{* * *} \\
(.041)\end{array}$ & $\begin{array}{l}.029 \\
(.049)\end{array}$ & $\begin{array}{l}.223^{* * *} \\
(.042)\end{array}$ & $\begin{array}{l}.028 \\
(.049)\end{array}$ & $\begin{array}{l}.223^{* * *} \\
(.042)\end{array}$ \\
\hline Married & $\begin{array}{l}.071 \\
(.077)\end{array}$ & $\begin{array}{c}.012 \\
(.127)\end{array}$ & $\begin{array}{l}.167^{\star \star \star *} \\
(.058)\end{array}$ & $\begin{array}{l}.022 \\
(.127)\end{array}$ & $\begin{array}{l}.166^{\star * *} \\
(.058)\end{array}$ & $\begin{array}{l}.022 \\
(.127)\end{array}$ & $\begin{array}{l}.166^{\star \star \star} \\
(.058)\end{array}$ \\
\hline \multicolumn{8}{|l|}{ Job Characteristics } \\
\hline Experience & $\begin{array}{l}.029^{\star * *} \\
(.012)\end{array}$ & $\begin{array}{l}.036 \\
(.023)\end{array}$ & $\begin{array}{l}-.013 \\
(.010)\end{array}$ & $\begin{array}{l}.034 \\
(.023)\end{array}$ & $\begin{array}{l}-.011 \\
(.010)\end{array}$ & $\begin{array}{l}.034 \\
(.023)\end{array}$ & $\begin{array}{l}-.011 \\
(.010)\end{array}$ \\
\hline Experience $S q$ & $\begin{array}{l}-.000 \\
(.000)\end{array}$ & $\begin{array}{l}-.001 \\
(.000)\end{array}$ & $\begin{array}{l}.001^{* * *} \\
(.000)\end{array}$ & $\begin{array}{l}-.000 \\
(.000)\end{array}$ & $\begin{array}{l}.001^{\star * *} \\
(.000)\end{array}$ & $\begin{array}{l}-.000 \\
(.000)\end{array}$ & $\begin{array}{l}.001^{* * *} \\
(.000)\end{array}$ \\
\hline Tenure & $\begin{array}{l}.020^{* * *} \\
(.008)\end{array}$ & $\begin{array}{l}.015 \\
(.011)\end{array}$ & $\begin{array}{l}.021^{* * *} \\
(.009)\end{array}$ & $\begin{array}{l}.016 \\
(.011)\end{array}$ & $\begin{array}{l}.021^{* * *} \\
(.009)\end{array}$ & $\begin{array}{l}.016 \\
(.011)\end{array}$ & $\begin{array}{l}.021^{* * *} \\
(.009)\end{array}$ \\
\hline Tenure Sq & $\begin{array}{l}-.000 \\
(.000)\end{array}$ & $\begin{array}{l}-.000 \\
(.000)\end{array}$ & $\begin{array}{l}-.000^{*} \\
(.000)\end{array}$ & $\begin{array}{l}-.000 \\
(.000)\end{array}$ & $\begin{array}{c}-.000^{* *} \\
(.000)\end{array}$ & $\begin{array}{l}-.000 \\
(.000)\end{array}$ & $\begin{array}{l}-.000^{* *} \\
(.000)\end{array}$ \\
\hline Small department & $\begin{array}{l}-.130 \\
(.082)\end{array}$ & $\begin{array}{l}-.186 \\
(.129)\end{array}$ & $\begin{array}{c}-.136^{\star *} \\
(.069)\end{array}$ & $\begin{array}{l}-.190 \\
(.129)\end{array}$ & $\begin{array}{l}-.133^{\star} \\
(.071)\end{array}$ & $\begin{array}{l}-.190 \\
(.130)\end{array}$ & $\begin{array}{l}-.133^{*} \\
(.072)\end{array}$ \\
\hline Large department & $\begin{array}{c}-.020 \\
(.0920)\end{array}$ & $\begin{array}{l}-.058 \\
(.143)\end{array}$ & $\begin{array}{l}.025 \\
(.076)\end{array}$ & $\begin{array}{l}-.053 \\
(143)\end{array}$ & $\begin{array}{l}.027 \\
(.076)\end{array}$ & $\begin{array}{l}-.052 \\
(.144)\end{array}$ & $\begin{array}{l}.027 \\
(.077)\end{array}$ \\
\hline Oxbridge $P h D$ & $\begin{array}{l}.123 \\
(.107)\end{array}$ & $\begin{array}{l}.125 \\
(.142)\end{array}$ & $\begin{array}{l}.338^{\star \star *} \\
(.147)\end{array}$ & $\begin{array}{l}.136 \\
(.142)\end{array}$ & $\begin{array}{l}.355^{\star * *} \\
(.147)\end{array}$ & $\begin{array}{l}.133 \\
(.144)\end{array}$ & $\begin{array}{l}.355^{\star \star \star} \\
(.148)\end{array}$ \\
\hline$P h D$ & $\begin{array}{l}.359^{\star \star *} \\
(.074)\end{array}$ & $\begin{array}{l}.407^{\star \star *} \\
(.123)\end{array}$ & $\begin{array}{l}.184^{\star \star *} \\
(.057)\end{array}$ & $\begin{array}{l}.420^{* \star *} \\
(.123)\end{array}$ & $\begin{array}{l}.169^{* \star *} \\
(.057)\end{array}$ & $\begin{array}{l}.425^{\star * *} \\
(.124)\end{array}$ & $\begin{array}{l}.169^{* \star *} \\
(.059)\end{array}$ \\
\hline Hours & $\begin{array}{l}.006^{*} \\
(.003)\end{array}$ & $\begin{array}{l}.010^{* *} \\
(.005)\end{array}$ & $\begin{array}{l}.001 \\
(.003)\end{array}$ & $\begin{array}{l}.011^{* *} \\
(.005)\end{array}$ & $\begin{array}{l}.001 \\
(.003)\end{array}$ & $\begin{array}{l}.011^{* *} \\
(.005)\end{array}$ & $\begin{array}{l}.001 \\
(.003)\end{array}$ \\
\hline Holiday & $\begin{array}{l}-.004 \\
(.003)\end{array}$ & $\begin{array}{l}-.005 \\
(.005)\end{array}$ & $\begin{array}{l}-.001 \\
(.003)\end{array}$ & $\begin{array}{l}-.005 \\
(.005)\end{array}$ & $\begin{array}{l}-.002 \\
(.003)\end{array}$ & $\begin{array}{l}-.005 \\
(.005)\end{array}$ & $\begin{array}{l}-.002 \\
(.003)\end{array}$ \\
\hline Time out & $\begin{array}{l}-.015 \\
(.019)\end{array}$ & $\begin{array}{l}-.011 \\
(.031)\end{array}$ & $\begin{array}{c}-.035^{* * *} \\
(.015)\end{array}$ & $\begin{array}{l}-.012 \\
(.031)\end{array}$ & $\begin{array}{c}-.037^{* * *} \\
(.015)\end{array}$ & $\begin{array}{l}-.013 \\
(.031)\end{array}$ & $\begin{array}{c}-.038^{* * *} \\
(.015)\end{array}$ \\
\hline \multicolumn{8}{|l|}{ Faculty } \\
\hline Science & $\begin{array}{l}-.062 \\
(.104)\end{array}$ & $\begin{array}{l}-.125 \\
(.153)\end{array}$ & $\begin{array}{l}-.051 \\
(.096)\end{array}$ & $\begin{array}{l}-.100 \\
(.153)\end{array}$ & $\begin{array}{l}-.031 \\
(.099)\end{array}$ & $\begin{array}{l}-.093 \\
(.154)\end{array}$ & $\begin{array}{l}-.031 \\
(.099)\end{array}$ \\
\hline Medicine & $\begin{array}{l}.293^{\star \star *} \\
(.096)\end{array}$ & $\begin{array}{c}.428^{* \star *} \\
(.153)\end{array}$ & $\begin{array}{l}.160^{*} \\
(.082)\end{array}$ & $\begin{array}{l}.457^{\star \star \star} \\
(.153)\end{array}$ & $\begin{array}{l}.150^{\star} \\
(.083)\end{array}$ & $\begin{array}{l}.449^{* * *} \\
(.154)\end{array}$ & $\begin{array}{l}.149^{*} \\
(.084)\end{array}$ \\
\hline Social Science & $\begin{array}{l}.151 \\
(.109)\end{array}$ & $\begin{array}{l}.187 \\
(155)\end{array}$ & $\begin{array}{l}-.073 \\
(.110)\end{array}$ & $\begin{array}{l}.215 \\
(.155)\end{array}$ & $\begin{array}{l}-.056 \\
(.111)\end{array}$ & $\begin{array}{l}.226 \\
(.156)\end{array}$ & $\begin{array}{l}-.056 \\
(.112)\end{array}$ \\
\hline Engineering & $\begin{array}{l}-.066 \\
(.125)\end{array}$ & $\begin{array}{l}-0.137 \\
(.183)\end{array}$ & $\begin{array}{l}-.009 \\
(.114)\end{array}$ & $\begin{array}{l}-.107 \\
(.184)\end{array}$ & $\begin{array}{l}.034 \\
(.117)\end{array}$ & $\begin{array}{l}-.106 \\
(.184)\end{array}$ & $\begin{array}{l}.034 \\
(.117)\end{array}$ \\
\hline Constant & $\begin{array}{c}-1.424^{\star * *} \\
(.242) \\
\end{array}$ & $\begin{array}{c}-1.772^{* * *} \\
(.417) \\
\end{array}$ & $\begin{array}{l}-.722 \\
(.204) \\
\end{array}$ & $\begin{array}{c}-1.683^{\star * *} \\
(.420) \\
\end{array}$ & $\begin{array}{c}-.719^{* * *} \\
(.203) \\
\end{array}$ & $\begin{array}{c}-1.695^{* * *} \\
(.421) \\
\end{array}$ & $\begin{array}{c}-.719^{\star \star *} \\
(.206) \\
\end{array}$ \\
\hline No of observations & 689 & 418 & 271 & 418 & 271 & 418 & 271 \\
\hline Adj. $R$ squared & .326 & .198 & .534 & .201 & .535 & .180 & .531 \\
\hline
\end{tabular}


Table 4: OLS

The determinants of individual productivity by contract type and promotion opportunity, dependent variable $=\mathrm{z}$-score of number of refereed publications by subject field

\begin{tabular}{|c|c|c|c|c|c|c|c|c|c|}
\hline No. of published papers & Grade 1 & Grade 2 & Grade 3 & Grade & Grade 2 & Grade 3 & Grade 1 & Grade 2 & Grade 3 \\
\hline \multicolumn{10}{|l|}{$\begin{array}{l}\text { Salary } \\
\text { Alot less than I deserve }\end{array}$} \\
\hline A lot less than I deserve & & & & & & & $\begin{array}{l}.106^{* *} \\
(.049)\end{array}$ & $\begin{array}{c}.104 \\
(.136)\end{array}$ & $\begin{array}{c}-1.300^{* * *} \\
(.468)\end{array}$ \\
\hline Less than I deserve & & & & & & & -.007 & .084 & $-.620^{*}$ \\
\hline & & & & & & & $(.037)$ & $(.101)$ & $(.367)$ \\
\hline More than I deserve & & & & & & & $\begin{array}{l}.207^{*} \\
(.115)\end{array}$ & $\begin{array}{c}.377 \\
(.282)\end{array}$ & $\begin{array}{l}-1.100 \\
(1.103)\end{array}$ \\
\hline A lot more than I deserve & & & & & & & .071 & 1.161 & -.019 \\
\hline & & & & & & $-794^{* *}$ & $(.868)$ & (2.391) & (1.930) \\
\hline Less & & & & $\begin{array}{l}.020 \\
(.035)\end{array}$ & $\begin{array}{l}.087 \\
(.098)\end{array}$ & $\begin{array}{l}-.794^{\star \star} \\
(.353)\end{array}$ & & & \\
\hline More & & & & $\begin{array}{l}.195^{*} \\
(.115)\end{array}$ & $\begin{array}{c}.387 \\
(.279)\end{array}$ & $\begin{array}{l}-.763 \\
(.977)\end{array}$ & & & \\
\hline Individual Characteristics & & & & & & & & & \\
\hline Male & $\begin{array}{l}.099^{\star \star *} \\
(.036)\end{array}$ & $\begin{array}{l}.279^{\star * *} \\
(.111)\end{array}$ & $\begin{array}{c}-0.430 \\
(1.421)\end{array}$ & $\begin{array}{l}.090^{\star \star *} \\
(.036)\end{array}$ & $\begin{array}{l}.270^{* \star *} \\
(.111)\end{array}$ & $\begin{array}{c}-0.861 \\
(1.415)\end{array}$ & $\begin{array}{l}.086^{\star \star *} \\
(.036)\end{array}$ & $\begin{array}{l}.268^{\star \star \star *} \\
(.112)\end{array}$ & $\begin{array}{c}-.463 \\
(1.430)\end{array}$ \\
\hline UK Citizen & $\begin{array}{l}.001 \\
(.049)\end{array}$ & $\begin{array}{l}.126 \\
(.142)\end{array}$ & $\begin{array}{c}-1.069 \\
(.849)\end{array}$ & $\begin{array}{l}.004 \\
(.049)\end{array}$ & $\begin{array}{l}.161 \\
(.144)\end{array}$ & $\begin{array}{c}-1-127 \\
(.835)\end{array}$ & $\begin{array}{l}-.003 \\
(.049)\end{array}$ & $\begin{array}{l}.161 \\
(.145)\end{array}$ & $\begin{array}{l}-.921 \\
(.843)\end{array}$ \\
\hline No. of Kids & $\begin{array}{l}.040 \\
(.026)\end{array}$ & $\begin{array}{l}.053 \\
(.041)\end{array}$ & $\begin{array}{l}.114 \\
(.147)\end{array}$ & $\begin{array}{l}.043^{*} \\
(.026)\end{array}$ & $\begin{array}{c}.052 \\
(.041)\end{array}$ & $\begin{array}{l}.070 \\
(146)\end{array}$ & $\begin{array}{l}.050^{*} \\
(.026)\end{array}$ & $\begin{array}{l}.052^{*} \\
(.041)\end{array}$ & $\begin{array}{l}.094 \\
(.146)\end{array}$ \\
\hline Married & $\begin{array}{l}-.052 \\
(.034)\end{array}$ & $\begin{array}{l}.069 \\
(.104)\end{array}$ & $\begin{array}{l}.070 \\
(.446)\end{array}$ & $\begin{array}{l}.041 \\
(.035)\end{array}$ & $\begin{array}{l}.063 \\
(.105)\end{array}$ & $\begin{array}{l}-.050 \\
(.442)\end{array}$ & $\begin{array}{l}.049 \\
(.035)\end{array}$ & $\begin{array}{c}.061 \\
(.105)\end{array}$ & $\begin{array}{l}-.046 \\
(.440)\end{array}$ \\
\hline \multicolumn{10}{|l|}{ Job Characteristics } \\
\hline Experience & $\begin{array}{l}.026^{\star * *} \\
(.006)\end{array}$ & $\begin{array}{l}.038^{*} \\
(.022)\end{array}$ & $\begin{array}{l}.105 \\
(.113)\end{array}$ & $\begin{array}{l}.027^{\star * *} \\
(.006)\end{array}$ & $\begin{array}{l}.033 \\
(.022)\end{array}$ & $\begin{array}{l}.075 \\
(.112)\end{array}$ & $\begin{array}{l}.025^{\star \star *} \\
(.006)\end{array}$ & $\begin{array}{l}.033 \\
(.022)\end{array}$ & $\begin{array}{l}.083 \\
(.111)\end{array}$ \\
\hline Experience $S q$ & $\begin{array}{l}-.001^{* * *} \\
(.000)\end{array}$ & $\begin{array}{l}-.001^{*} \\
(.001)\end{array}$ & $\begin{array}{l}-.001 \\
(.002)\end{array}$ & $\begin{array}{c}-.001^{* \star *} \\
(.000)\end{array}$ & $\begin{array}{l}-0.000 \\
(000)\end{array}$ & $\begin{array}{l}-.001 \\
(.002)\end{array}$ & $\begin{array}{c}-.001^{* \star *} \\
(000)\end{array}$ & $\begin{array}{l}-.001 \\
(001)\end{array}$ & $\begin{array}{l}-.001 \\
(.002)\end{array}$ \\
\hline Tenure & $\begin{array}{l}.022^{\star \star *} \\
(.006)\end{array}$ & $\begin{array}{l}.031^{\star *} \\
(.016)\end{array}$ & $\begin{array}{l}-.003 \\
(.043)\end{array}$ & $\begin{array}{l}.021^{* * *} \\
(.006)\end{array}$ & $\begin{array}{l}.033^{\star \star} \\
(.016)\end{array}$ & $\begin{array}{l}.012 \\
(.043)\end{array}$ & $\begin{array}{c}.020^{\star \star *} \\
(.006)\end{array}$ & $\begin{array}{l}.033^{\star *} \\
(.016)\end{array}$ & $\begin{array}{l}.012 \\
(.043)\end{array}$ \\
\hline Tenure $S q$ & $\begin{array}{c}-.000^{* * *} \\
(.000)\end{array}$ & $\begin{array}{l}-.000 \\
(.001)\end{array}$ & $\begin{array}{l}.001 \\
(.001)\end{array}$ & $\begin{array}{c}-.000^{* * *} \\
(.000)\end{array}$ & $\begin{array}{l}-.001 \\
(.001)\end{array}$ & $\begin{array}{l}.001 \\
(.001)\end{array}$ & $\begin{array}{c}-.000^{* * *} \\
(.000)\end{array}$ & $\begin{array}{l}-.001 \\
(.001)\end{array}$ & $\begin{array}{l}.000 \\
(.001)\end{array}$ \\
\hline Small department & $\begin{array}{c}-.091^{* *} \\
(.040)\end{array}$ & $\begin{array}{l}.000 \\
(.110)\end{array}$ & $\begin{array}{l}-.561 \\
(.423)\end{array}$ & $\begin{array}{c}-.101^{\star * *} \\
(.042)\end{array}$ & $\begin{array}{l}-.017 \\
(.110)\end{array}$ & $\begin{array}{l}-.779^{\star} \\
(.427)\end{array}$ & $\begin{array}{c}-.119^{* \star *} \\
(.042)\end{array}$ & $\begin{array}{l}-.016 \\
(.444)\end{array}$ & $\begin{array}{l}-.770^{\star} \\
(.435)\end{array}$ \\
\hline Large department & $\begin{array}{l}-.008 \\
(.047)\end{array}$ & $\begin{array}{l}.010 \\
(.123)\end{array}$ & $\begin{array}{l}-.485 \\
(.425)\end{array}$ & $\begin{array}{l}-.012 \\
(.047)\end{array}$ & $\begin{array}{l}.005 \\
(123)\end{array}$ & $\begin{array}{l}-.546 \\
(.418)\end{array}$ & $\begin{array}{l}-.018 \\
(.047)\end{array}$ & $\begin{array}{l}.004 \\
(.124)\end{array}$ & $\begin{array}{l}-.589 \\
(.431)\end{array}$ \\
\hline Oxbridge $P h D$ & $\begin{array}{l}.081 \\
(.086)\end{array}$ & $\begin{array}{l}.186 \\
(.131)\end{array}$ & $\begin{array}{c}-.971^{\star \star *} \\
(.379)\end{array}$ & $\begin{array}{l}.080 \\
(.087)\end{array}$ & $\begin{array}{l}.191 \\
(.132)\end{array}$ & $\begin{array}{c}-.908^{\star \star *} \\
(.378)\end{array}$ & $\begin{array}{l}.062 \\
(.086)\end{array}$ & $\begin{array}{l}.190 \\
(.132)\end{array}$ & $\begin{array}{c}-.994^{\star * *} \\
(.382)\end{array}$ \\
\hline$P h D$ & $\begin{array}{l}.158^{* * *} \\
(.036)\end{array}$ & $\begin{array}{l}.397^{* * *} \\
(.096)\end{array}$ & $\begin{array}{l}.680^{*} \\
(.410\end{array}$ & $\begin{array}{l}.154^{* * *} \\
(.036)\end{array}$ & $\begin{array}{l}.379^{* * *} \\
(.097)\end{array}$ & $\begin{array}{l}.855^{\star *} \\
(.410)\end{array}$ & $\begin{array}{l}.141^{\star \star *} \\
(.036)\end{array}$ & $\begin{array}{l}.379^{* * *} \\
(.099)\end{array}$ & $\begin{array}{l}.885^{\star \star} \\
(.408)\end{array}$ \\
\hline Hours & $\begin{array}{l}.003^{\star \star} \\
(.002)\end{array}$ & $\begin{array}{l}.007 \\
(.004)\end{array}$ & $\begin{array}{l}-.020 \\
(.015)\end{array}$ & $\begin{array}{l}.003^{* *} \\
(.002)\end{array}$ & $\begin{array}{l}.006 \\
(.004)\end{array}$ & $\begin{array}{l}-.014 \\
(.015)\end{array}$ & $\begin{array}{l}.003^{\star *} \\
(.002)\end{array}$ & $\begin{array}{l}.006 \\
(.004)\end{array}$ & $\begin{array}{l}-.013 \\
(.016)\end{array}$ \\
\hline Holiday & $\begin{array}{l}-.010 \\
(.002)\end{array}$ & $\begin{array}{l}.007 \\
(.004)\end{array}$ & $\begin{array}{c}-.040^{* *} \\
(.020)\end{array}$ & $\begin{array}{l}-.002 \\
(.002)\end{array}$ & $\begin{array}{l}.006 \\
(.004)\end{array}$ & $\begin{array}{c}-.039^{* *} \\
(.019)\end{array}$ & $\begin{array}{l}-.002 \\
(.002)\end{array}$ & $\begin{array}{l}.006 \\
(.004)\end{array}$ & $\begin{array}{c}-.045^{\star \star \star} \\
(.020)\end{array}$ \\
\hline Time out & $\begin{array}{l}.006 \\
(.008)\end{array}$ & $\begin{array}{l}-.047 \\
(.033)\end{array}$ & $\begin{array}{l}-.870 \\
(.894)\end{array}$ & $\begin{array}{l}.004 \\
(.008)\end{array}$ & $\begin{array}{l}-.047 \\
(.033)\end{array}$ & $\begin{array}{l}-.957 \\
(.882)\end{array}$ & $\begin{array}{l}.004 \\
(.008)\end{array}$ & $\begin{array}{l}-.048 \\
(.033)\end{array}$ & $\begin{array}{l}-.629 \\
(.901)\end{array}$ \\
\hline Faculty & & & & & & & & & \\
\hline Science & $\begin{array}{l}-.075 \\
(.055)\end{array}$ & $\begin{array}{l}-.083 \\
(.131)\end{array}$ & $\begin{array}{l}.510 \\
(.507)\end{array}$ & $\begin{array}{l}-.079 \\
(.056)\end{array}$ & $\begin{array}{l}-.100 \\
(.132)\end{array}$ & $\begin{array}{l}.468 \\
(.500)\end{array}$ & $\begin{array}{l}-.085 \\
(.056)\end{array}$ & $\begin{array}{l}-.097 \\
(.133)\end{array}$ & $\begin{array}{l}.441 \\
(505)\end{array}$ \\
\hline Medicine & $\begin{array}{l}.028 \\
(.048)\end{array}$ & $\begin{array}{l}.333^{* * *} \\
(.128)\end{array}$ & $\begin{array}{c}1.060^{* *} \\
(.495)\end{array}$ & $\begin{array}{l}.018 \\
(.049)\end{array}$ & $\begin{array}{l}.313^{\star * \star} \\
(.129)\end{array}$ & $\begin{array}{c}1.130^{* *} \\
(.494)\end{array}$ & $\begin{array}{l}.019 \\
(.048)\end{array}$ & $\begin{array}{c}.314^{\star \star \star} \\
(.129)\end{array}$ & $\begin{array}{c}1.104^{* *} \\
(.492)\end{array}$ \\
\hline Social Science & $\begin{array}{l}-.115^{\star} \\
(.059)\end{array}$ & $\begin{array}{c}.069 \\
(.138)\end{array}$ & $\begin{array}{c}.433 \\
(.500)\end{array}$ & $\begin{array}{c}-.119^{* *} \\
(.060)\end{array}$ & $\begin{array}{c}.050 \\
(.139)\end{array}$ & $\begin{array}{l}.596 \\
(.499)\end{array}$ & $\begin{array}{c}-.122^{* *} \\
(.060)\end{array}$ & $\begin{array}{l}.046 \\
(.141)\end{array}$ & $\begin{array}{c}.651 \\
(.502)\end{array}$ \\
\hline Engineering & $\begin{array}{l}-.091 \\
(.068)\end{array}$ & $\begin{array}{c}.029 \\
(.152)\end{array}$ & $\begin{array}{l}-.164 \\
(.585)\end{array}$ & $\begin{array}{l}-.097 \\
(.069)\end{array}$ & $\begin{array}{c}.001 \\
(.153)\end{array}$ & $\begin{array}{l}.014 \\
(.580)\end{array}$ & $\begin{array}{l}-.097 \\
(.069)\end{array}$ & $\begin{array}{c}.003 \\
(.154)\end{array}$ & $\begin{array}{l}.146 \\
(.582)\end{array}$ \\
\hline Constant & $\begin{array}{r}.926^{\star * *} \\
(.119) \\
\end{array}$ & $\begin{array}{c}-1.870^{* * *} \\
(.374) \\
\end{array}$ & \begin{tabular}{|c|}
1,962 \\
$(2.830)$ \\
\end{tabular} & \begin{tabular}{|c}
$-.915^{\star * *}$ \\
$(.119)$ \\
\end{tabular} & \begin{tabular}{|c}
$-1.860^{* * *}$ \\
$(.375)$ \\
\end{tabular} & $\begin{array}{c}2.966 \\
(12.91) \\
\end{array}$ & \begin{tabular}{|c}
$-.871^{\star * *}$ \\
.119 \\
\end{tabular} & $\begin{array}{c}1.853^{* \star *} \\
.379 \\
\end{array}$ & $\begin{array}{c}2.223 \\
(2.872) \\
\end{array}$ \\
\hline No of observations & 299 & 286 & 104 & 299 & 286 & 104 & 299 & 286 & 104 \\
\hline Adj. $R$ squared & .359 & .224 & .130 & .361 & .225 & .161 & .371 & .219 & .170 \\
\hline
\end{tabular}




\section{IZA Discussion Papers}

\begin{tabular}{|c|c|c|c|c|}
\hline No. & Author(s) & Title & Area & Date \\
\hline 420 & $\begin{array}{l}\text { Å. Rosén } \\
\text { E. Wasmer }\end{array}$ & $\begin{array}{l}\text { Higher Education Levels, Firms' Outside Options } \\
\text { and the Wage Structure }\end{array}$ & 1 & $01 / 02$ \\
\hline 421 & P. Manzini & Divide et Impera: Negotiating with a Stakeholder & 6 & $02 / 02$ \\
\hline 422 & $\begin{array}{l}\text { J. T. Addison } \\
\text { L. Bellmann } \\
\text { C. Schnabel } \\
\text { J. Wagner }\end{array}$ & $\begin{array}{l}\text { The Long Awaited Reform of the German Works } \\
\text { Constitution Act }\end{array}$ & 6 & $02 / 02$ \\
\hline 423 & $\begin{array}{l}\text { E. Feess } \\
\text { G. Muehlheusser }\end{array}$ & Transfer Fee Regulations in European Football & 1 & $02 / 02$ \\
\hline 424 & $\begin{array}{l}\text { F. Büchel } \\
\text { M. van Ham }\end{array}$ & $\begin{array}{l}\text { Overeducation, Regional Labour Markets and } \\
\text { Spatial Flexibility }\end{array}$ & 3 & $02 / 02$ \\
\hline 425 & F. Büchel & $\begin{array}{l}\text { Successful Apprenticeship-to-Work Transitions: } \\
\text { On the Long-Term Change in Significance of the } \\
\text { German School-Leaving Certificate }\end{array}$ & 3 & $02 / 02$ \\
\hline 426 & $\begin{array}{l}\text { J. Hartog } \\
\text { W. P. M. Vijverberg }\end{array}$ & $\begin{array}{l}\text { Do Wages Really Compensate for Risk Aversion } \\
\text { and Skewness Affection? }\end{array}$ & 5 & $02 / 02$ \\
\hline 427 & D. Del Boca & $\begin{array}{l}\text { The Effect of Child Care and Part Time } \\
\text { Opportunities on Participation and Fertility } \\
\text { Decisions in Italy }\end{array}$ & 6 & $02 / 02$ \\
\hline 428 & D. Del Boca & $\begin{array}{l}\text { Mothers, Fathers and Children after Divorce: } \\
\text { The Role of Institutions }\end{array}$ & 6 & $02 / 02$ \\
\hline 429 & $\begin{array}{l}\text { S. Anger } \\
\text { J. Schwarze }\end{array}$ & $\begin{array}{l}\text { Does Future PC Use Determine Our Wages } \\
\text { Today? Evidence from German Panel Data }\end{array}$ & 5 & $02 / 02$ \\
\hline 430 & $\begin{array}{l}\text { J. Schwarze } \\
\text { M. Härpfer }\end{array}$ & $\begin{array}{l}\text { Are People Inequality Averse, and Do They } \\
\text { Prefer Redistribution by the State? Evidence } \\
\text { From German Longitudinal Data on Life } \\
\text { Satisfaction }\end{array}$ & 3 & $02 / 02$ \\
\hline 431 & $\begin{array}{l}\text { M. Fertig } \\
\text { C. M. Schmidt }\end{array}$ & $\begin{array}{l}\text { The Perception of Foreigners and Jews in } \\
\text { Germany - A Structural Analysis of a Large } \\
\text { Opinion Survey }\end{array}$ & 6 & $02 / 02$ \\
\hline 432 & E. Tekin & $\begin{array}{l}\text { Employment, Wages, and Alcohol Consumption } \\
\text { in Russia: Evidence from Panel Data }\end{array}$ & 4 & $02 / 02$ \\
\hline 433 & $\begin{array}{l}\text { J. D. Angrist } \\
\text { A. D. Kugler }\end{array}$ & $\begin{array}{l}\text { Protective or Counter-Productive? Labor Market } \\
\text { Institutions and the Effect of Immigration on EU } \\
\text { Natives }\end{array}$ & 3 & $02 / 02$ \\
\hline 434 & A. D. Kugler & $\begin{array}{l}\text { From Severance Pay to Self-Insurance: Effects } \\
\text { of Severance Payments Savings Accounts in } \\
\text { Colombia }\end{array}$ & 4 & $02 / 02$ \\
\hline 435 & $\begin{array}{l}\text { G. S. Epstein } \\
\text { M. E. Ward }\end{array}$ & $\begin{array}{l}\text { Perceived Income, Promotion and Incentive } \\
\text { Effects }\end{array}$ & 1 & $02 / 02$ \\
\hline
\end{tabular}

